\title{
Poetry and the Politics of Memory
}

\author{
Dr. Doina Uricariu \\ Director, Romanian Cultural Institute New York, 200 East $38^{\text {th }}$ Street \\ New York 10016, USA \\ doina.uricariu@gmail.com, doina.uricariu@icrny.org
}

\begin{abstract}
The politics of memory are full of acts of censorship, of anamorphoses, of provoked or induced amnesias, of therapies, of lobotomies, before they are attributed to psychoanalisys, left in the care of Freud and Jung, of Marxist-Leninism, of cosummerism, populism, minimalism and post-modernism. I will read you a few poems and I will tell you a little bit about my volumes of memoirs simply in order to point out that poetry signifies memory and history. This implicitly brings to mind the Sighet Memorial, a place which gathers and recounts of poems written, passed on, and memorized in prisons. Memory is an essential bridge between two shores. That is why I wished so intently to bring recently the Sighet Memorial across the Atlantic Ocean, as well as on the East Coast of the USA, and further on on its West Coast. Memory defines us and becomes our true identification card, which may become also our driver's licence into the future, isn't it?
\end{abstract}

De-a lungul turneului de literatură şi de prezentare a muzeului de la Sighet, pe care 1-am avut în California, după evenimentele de la Book Expo America, de la Javits Center, şi cele din Auditorium Hall, de la Institutul Cultural Roman din New York, în timpul lecturilor de la Biblioteca Congresului SUA şi de la Ambasada României, la Washington, m-am gândit la cutremurătoarea istorie vie a comunismului în România şi la soarta acestei memorii în postcomunism. Ce s-ar fi întâm-plat cu istoria şi memoria Gulagului româ-nesc, a vieţilor fiecăruia dintre noi în comu-nism, dacă ea nu ar fi fost prezentată de memorialul de la Sighet şi de cărţile publicate de Academia Civică sau de alte edituri, unde au apărut cărţile detenţiei, depoziţiile depor-taţilor, jurnalele rezistenţei şi paginile disi-denţei reale, nu contrafăcute.

M-am gândit la memoria acelor vremuri, aşa cum mai persistă în fiecare dintre noi şi în creaţia noastră.

Memoria umană este un material vernacular, care ne construieşte şi ne defineşte.

Așa cum în arhitectura vernaculară sunt ziditoare pământul chirpicilor, lemnul şi piatra, stuful şi... pădurile de bambus...
Vorbind despre cartile mele de memorii, peste 3000 de pagini scoase în 4 volume, sub titlul Maxilarul inferior şi Scara leilor, m-am gândit la miracolul memoriei umane, ca la o geneză şi reconstrucţie de sine. Nu o să vă vorbesc dvs. însă despre ceea ce oamenii de ştiinţă consideră drept "a neural super-computer of huge capacity and speed", nici despre "different types of memory, des-pre "our short term and long term memories, as encoded and stored in different ways and parts of the brain", "about the enigma that is the human memory".

O să vă propun să ne gândim la memorie, memorii, istorie şi literatură din perspectiva unei afirmaţii făcute de marele actor englez Jeremy Irons. Poate vi-1 amintiţii din multe filme. Poate 1-aţi văzut în Maşina timpului /The Time Machine, filmat în 2002. "We all have our time machines. Some take us back, they are called memories. Some take us for-ward, they're called dreams." Uneori simplificările şi utopiile sau distopiile din filme ne ajută să vizualizăm realităţi pe care ochiul nostru le pierde din vedere. $\mathrm{Cu}$ toţii avem o maşină a timpului cu care călătorim spre tre-cut şi spre viitor. În 
fiecare dintre cărţile pe care le-am scris, vuiesc motoarele acestei maşini sau se aud zgomotele trăsurilor, căru-ţelor, bicicletei sau ale roţilor de tren purtând călători, deportaţi spre câmpuri de muncă forţată sau lagăre de exterminare. În poemele mele din comunism auziţi şi o maşină a tim-pului raţionalizată, funcţionând cu benzină pe cartelă. O maşină sau care circula, în funcţie de numărul par sau impar, sub care era înmatriculată, doar în duminicile cu soţ sau fără soţ. Politicile memoriei dictează spălarea creierelor sau experimentul Piteşti care a asmuţit victimele unele împotriva altora, transformându-i pe deţinuţi în torţionari şi criminali, printr-o clonare a infernului şi josniciei amorale. Martirii sunt preschimbaţi în Iuda.

Memories, poetry, history are influenced by political and cultural forces. We can understand the political means by which different events are remembered or discarded, or recorded and presented in poems, history, literature and mentalities. Politics of memory are shaping collective memory, the way history is written and passed on. I understood how the politics of memory are working in Romania, după felul în care in-stituţia monarhiei şi Familia Regală au fost prezentaţi poporului român după 1990 şi pâ-nă azi. Şi pe propria mea piele de scriitor. De la ameninţările cu moartea pe care le-am primit după primul interviu cu regele Mihai pe care l-am publicat cea dintâi în România, în România Literară în 23 august 1990 şi până la publicarea acestor patru volume de memorii Maxilarul inferior şi Scara leilor, ambele titluri, bestselluri la scala României, nominalizate la Premiile Uniunii Scriitorilor şi Premiile Asociaţiei Scriitorilor Bucureşti, la Premiul pentru proză şi eseu şi la premiile special ale revistei Observator cultural dar nepremiate în final decât cu premiul pu-blicului acordat de revista Observator cultural şi Premiul pentru proză al revistei Convorbiri literare. Dat fiind că spiritul re-publican, antimonarhist nu agrea perspec-tiva şi mai ales procesul de recuperare al memoriei valorilor monarhiei.

Politicile memoriei sunt pline de acte ale cenzurii, de anamorfoze, de amnezii provocate şi induse, de terapii, de loboctomii, îna-inte să fie trecute în seama psihanalizei, pe mâna lui Freud, a lui Jung, a Marxism leni-nismului, a consumismului, populismului, minimalismului şi postmodernismului. Me-mories, history and poetry, are written and seen, and influenced by cultural and political forces. Government policies, social norms, popular culture, social rules influence the way events are remembered.

O să vă citesc câteva poeme şi o să vă povestesc puţin despre cărţile mele de memorii doar pentru a ne aminti că poezia înseamnă memorie şi istorie, ceea ce ne reaminteşte inclusiv Memorialul de la Sighet care adună şi povesteşte despre poeziile scrise, transmise şi memorate în închisori. Memoria este o punte esenţială între două maluri. De aceea am dorit atât de puternic să aduc memorialul de la Sighet peste Oceanul Atlantic şi mai departe, la Oceanul Pacific, pe Coasta de Vest. Memoria la care ne ra-portăm este actul nostru de identitate, care poate fi şi permisul nostru de conducere, nu-i asa? To Read Poems Between Wedding Candles 
I wrote this well-behaved poem in the memory of an evening of poetry reading, a long time ago, during the Communist Regime in Romania. I recited my poems in the meeting hall of a provincial Cultural Center, with the electricity turned off by order of the Mayor. We, the poets, were gathered on the stage. The hall was filled beyond capacity, a black box, illuminated by only two large wedding candle-sticks brought in by someone in the audience.

In this country blessed by the lamp of Ilyich Lenin

there is no light but at hours most descent the light bulbs are put to sleep

just like bodies removed from the living.

Up on the stage, inside this black box we read long poems in the dark we huddle among the wedding candles that burn so light may be shed on these times.

Lonely, among the white canes

Of wax that sputter on the shores

The words of Issaiah dancing

Are different somehow on the page turned

one speaks of road dust, of haystacks with mint-flavor

one speaks of the bird's crucified flight the poet is but a lonely groom that descends and is wedded for times better or worse

still lingering there, among the burnt ribbons

are round rings, the home of the candle bearing the wedding mark on its shoulders a guarding angel opens the gates of the prison.

he, among candles, in the dark depth of this box

the long poem read under the light of the candle,

Did the gates open of your Heavenly Kingdom?

in this country of light bulbs ever-ordered to sleep.
Să citeşti poeme între lumânările de la cununie.

Am scris acest poem cuminte în amintirea unei seri de poezie în care am citit la un cămin cultural poeme într-o sală cu lumina stinsă în urma ordinului primit de la județ. Eram complet în întuneric, noi scriitorii pe scenă şi sala plină ca o cutie neagră, având drept luminădoar două lumânări de cununie aduse de cineva.

În ţara blagoslovită de lampa lui Ilici nu e lumină decât la ore decente becurile sunt trimise să doarmă ca nişte trupuri din viaţă absente.

Urcaţi pe scenă, în cutia neagră citim în întuneric lungi poeme stăm între lumânările de cununie ce ard spre a lumina această vreme.

Însinguraţi, între toiagurile albe de ceară care sfărie în maluri Cuvintele din Isaia dănţuieşte Sunt altele jucând pe foaia-ntoarsă

vorbeşti de colburi, de căpiţe, cu miros de mentă

de crucea păsării din înălţime

poetul ca un mire singur

la bine şi la rău coboară în sine.

mai stăruie acolo, în panglicile arse verigile rotunde, lăcaşul lumânării cu semnul cununiei lângă umeri un înger păzitor deschide poarta închisorii.

el între lumânări, în întunericul cutiei poemul lung citit la lumânare, de parcă s-ar fi deschis porţile împărăţiei? în ţara cu becurile trimise mereu la culcare 


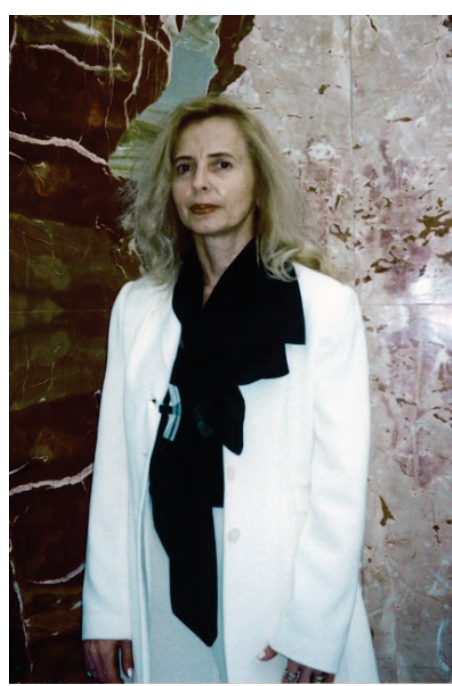

About DOINA URICARIU:

By Doreen Schmidt, Editor, Napa Valley, California, USA

Rare is the poet who fluidly captures the world in its tiniest to most expansive detail. Uricariu's ecstatic delight dances across the page in precisely and perfectly chosen words. Those words abound and revel in the visceral elements of flora, fauna and minerals. It is illuminating to encounter a poet with such insistent and red-blooded reverence for nature and passion, baby goats and oracke, cornsilk and dandelions, roots and ore, agate and olives, pegmatites and chalcedony, architectures of man and nature. She enters the earth, rolls around inside it, paints its walls with words vibrant as blood, with war paint's urgency.

Uricariu deftly weaves together concepts that we in the West don't often experience through our poets: the sacred and spiritual, the ecstatic and mundane, who writes in wonder that "God was about to teach light how to write." Her work is informed but not encumbered by the orthodoxy of her religious belief, her words unblemished by twisted interpretations belonging to others. She wears her spirituality like Rumi: another rare and visceral, light-filled, reverent presence. It is all the same for her: her fervent embrace of religion, nature, sexuality and maternality. Why should it be otherwise? In a segmented society that often segregates earthly and spiritual concerns, the whole and every part of the whole, it is refreshing to be reminded of their integrity and integral connectivity by a poet who writes as she believes: with a child's purity, a purist's specificity, an academic's erudition, a poet's faith.

Doina Uricariu is an important contemporary Romanian writer with an unmistakable lyric voice born out of a generous sensuous universe, intersected by constant moral, philosophical, and political questioning. She started out in poetry with the volume Healings, published in 1976 after a seven-year wait in the hands of the Communist censorship. Eight other volumes of poetry followed: Jugastru Sfiala, Happy Beings, The Hand-covered Face, Atrocious Eye, The Heart Institute, The Power of Leviathan, The Axonometric Heart, three volumes of poetry published in Italy, a bi-lingual GermanRomanian volume of poetry Das Herzinstitut / The Heart Institute.

Mrs. Uricariu's poetry has been translated in anthologies and individual volumes in English, German, French, Swedish, Norwegian, Russian, Serbian, Czech, Hebrew, Albanian and in other twenty languages. She published volumes of criticism and literary history, essays, and art criticism that are considered milestones on their respective subjects: Apocrypha on Emil Botta, Ecorches, Paradoxical Lyricism, Søren Kierkegaard, Maria Pillat-Brates: Poetry and Reverie, Antonovici, Vlaicu Ionescu, the Artist. Doina Uricariu prepared and edited reference editions on Emil Cioran, Dominic Stanca, Jeni Acterian, Emil Botta, and The Podrom Filokalia. She published four volumes of her memoirs in two books entitled The Lower Jaw and The Lions Stair.

Dr. Doina Uricariu is member of Romanian Writers Association, European Cultural Society, and International PEN CLUB. Knight of the Order of Faithful Service of Romania conferred by the President of the country. Knight of the Order of the Romanian Crown conferred by the Royal House of Romania. She is currently the director of the Romanian Cultural Institute in New York. 